Annals of Warsaw University of Life Sciences - SGGW

Horticulture and Landscape Architecture No 41, 2020: 63-75

(Ann. Warsaw Univ. of Life Sci. - SGGW, Horticult. Landsc. Architect. 41, 2020)

DOI 10.22630/AHLA.2020.41.6

\title{
Landscape accessibility in terms of Polish law. Can everyone use urban open spaces in Poland?
}

KAMIL LESZEK RAWSKI

Faculty of Architecture, Bialystok University of Technology

\begin{abstract}
Landscape accessibility in terms of Polish law. Can everyone use the urban open spaces in Poland? The article presents problems of designing urban open spaces (UOSs) in the context of their accessibility for individual users from various angles. First, it analyses aspects that should be taken into account, especially those that can contribute to the increase in UOSs' accessibility and safety for people with special needs. Second, it considers issues pertaining to legal provisions that define design guidelines for individual elements of a space. Next, the paper also examines recent support for disabled people by the government, in particular the governmental programme "Accessibility Plus" and the new Accessibility Law. And finally, this publication is also an attempt to determine the general state of accessibility of UOSs located in Poland in relation to existing legal provisions. The law that does not oblige designers to plan accessibility with specific regulations cannot ensure UOSs' accessibility. The article expounds that legal provisions should be stated as clear guidelines, and despite the fact that the Polish government is attempting to improve the present situation, the author postulates that further changes are needed.
\end{abstract}

Key words: universal design, accessibility, landscape architecture objects, people with disabilities, people with special needs, barriers

\section{INTRODUCTION}

One of the most important aspects of a public space is its accessibility. The literature of the subject emphasises that a public space should be available to all interested parties (Wejchert 1993). Dymicka states that "all the citizens should have guaranteed access to such space [own translation]" (Dymicka 2013, p. 21), while Lorens adds that they should be physically available to all interested persons. He also notes that "space accessibility may be restricted, however, only for a limited period of time, due to security issues or use organization [own translation]" (Lorens and Martyniuk-Pęczek 2010, p. 10). Nevertheless, it is worth pointing out that the legal definition of a public space does not emphasise its accessibility aspects. According to the Act of 27 March 2003 on spatial planning and development' an area of public space should be understood as "the area of special importance for meeting the needs of residents, improving their quality of life and conducive to establishing the social contacts due to its location as well as functional and spatial features, defined in the legal documents on local spatial planning [own translation]". On the one hand, this term includes areas such as a town square, park square, park or even boulevards, promenades or streets. On the other, however, many of these places are not noted and labelled as public spaces in the local zoning plans. Indeed, some areas are not covered by the document at all. With this in mind, 
the theme scope of public spaces is narrowed here to urban open spaces (UOSs). Notwithstanding the fact that the term is not legally defined, it is necessary to focus on what exactly such objects are and what they include. Source materials may prove valuable here. The first explanation is provided by governmental website about different professions' specifications www.praca.gov.pl. According to it, in the description of landscape architect occupation UOSs include:

- "gardens (botanical, allotment, home, housing estate, courtyard, and roof);

- residences parks and gardens;

- parks (public, ethnographic, and health resorts);

- others (squares, boulevards, sports grounds, playgrounds, garden exhibitions, and cemeteries) [own translation]" (www.praca.gov.pl, accessed: 29.02.2020).

A part of the UOSs mentioned above is private, but the majority constitute public spaces. Wolski and Böhm also made an attempt ${ }^{1}$ at an essential definition and specified that UOSs are "permanently or temporarily developed areas, which have been given specific utility and aesthetic values, using vegetation and other natural elements, and are works of human hands [own translation]" (SARP Warszawa 2017).

Another research was performed by the Project for Public Spaces ${ }^{2}$, which

\footnotetext{
${ }^{1}$ In the form of explanation to the project of education standard for landscape architecture course of study 13 July 2006 (more: SARP Warszawa 2017). ${ }^{2}$ Project for Public Spaces is a non-profit planning, design, and educational organisation dedicated to helping people create and sustain public spaces that build stronger communities (https:// www.pps.org/about, accessed: 02.03.2020).
}

conducted the research to determine the main features of a well-designed space for people. Based on a study of over a thousand public spaces, four main traits were identified, namely accessibility, functionality, comfort of use, and social value (Madden and WileySchwartz 2005). Among these, the first one, accessibility, seems to be the most important. To meet the other features it must be possible to easily get into and freely move around in a given place, which boils down to the fact that everyone should be able to use it. However, it should be stressed that many a time it is only a privilege for the healthy, not the disadvantaged. Nevertheless, there is a noticeable increase in the awareness of designers and legislators in considering accessibility for all people, including those with disabilities. As a result, one can find provisions requiring an adaptation of individual elements of the space for disabled people in Polish law. Be this as it may, accessibility is often determined by economic aspects; therefore, solutions that are applied, although in accordance with the law, do not always solve the problem holistically. In addition to this, some laws conflict with others. This is due to the fact that some old legal provisions have not changed with the introduction of new ones (Kowalski 2013).

The accessibility of a place can be considered in terms of logistics, which is understood here as ease of getting to the place, regardless of being healthy or moving with the help of some aid, e.g. in a wheelchair. In turn, the comfort of use is a result of how much effort should be put into navigating such an area. The accessibility of a space will also depend 
on its security. Ultimately, many factors could determine whether a place is accessible to everyone or only to some; moreover, it depends on the needs of the potential users of the space. According to the idea of universal design, not only disabled people should be considered. Among people with special needs there are: people with limited mobility, blind and visually impaired people, deaf people, people with perception disorders, elderly people, pregnant women, parents with children (and strollers), as well as people with untypical heights. Thus, the issue of accessibility for everyone is a very complex one. In recent literature on the subject, although related more to tourism than architecture, the concept of hospitable space is introduced which shows the core of the issue in a wider scope. As Kaczmarek and Kaczmarek (2011) describe, the very concept of hospitality can be understood as an offer of services or a gift of residents for people coming to their homes. This indicates that a hospitable space is a way of developing the area, enabling a safe and comfortable stay for visitors. Such an area is characterised by:

- spatial order, high level of aesthetics;

- an orderly, readable and widely understood information system;

- lack of barriers, enabling universal and easy access to key places (also for the disabled, the elderly, or children);

- friendly attitude towards visitors;

- sense of security during the stay.

To design accessible places, it is necessary to develop specific design guidelines based on the needs of individual users. Currently, accessibility standards are increasingly being created, with individ- ual cities drawing up guidelines for planning the accessibility of a space. Some local authorities (e.g. of Gdynia, Warsaw, Wrocław) have attempted to create guidelines aimed at specifying how to design green and recreation areas (Wysocki 2013, Rymsza and Miśkowiec 2017, Tota 2019). These are presented in the form of specific recommendations, and only apply inside the municipal boundary and relate to the areas at the disposal of the local government. Standards may also vary depending on the responsible department; hence we postulate a necessity to unify them in order for them to be applied on a national scale. Taking into account the possibility of financing various projects from the European Union budget, they must be compatible with the idea of equalising opportunities for people with special needs. For this purpose, there were created specific guidelines and recommendations (MIiR 2018). However, once again, they do not oblige all designers, but only stakeholders of EU subsidies. Therefore, to be able to assume that UOSs are accessible for everyone, the main legal acts that condition space designing should now be analysed.

\section{MATERIAL AND METHODS}

The key research question is to determine if everyone is able to use UOSs. On the basis of an examination of the literature, we raise issues related to the accessibility of public spaces, with particular emphasis on references to UOSs' design. We assume that UOSs' accessibility is determined by appropriate legal provisions. Otherwise, it is dependent 
upon the designer's goodwill. The research mainly comprises a review of the law referring to the design of accessible space with the aim of establishing its involvement in planning space accessibility, especially that of USOs. In addition to this, we analyse legal provisions to examine whether they oblige designers to plan UOSs' accessibility. Principally the following legal documents were accounted for:

- Constitution of the Republic of Poland of 2 April 1997;

- Regulation of the Minister of Infrastructure of 12 April 2002 on technical requirements to be met by buildings and their location;

- Regulation of the Minister of Transport and Maritime Economy of 2 March 1999 on technical requirements to be met by public roads and their location.

Next, the needs of potential users of given spaces were identified to determine those elements that constitute barriers to them. Guidelines should mostly concern the following categories:

- communication routes;

- overcoming height differences (ramps, terrain stairs);

- space equipment (such as rest areas, trash cans, information boards, fountains);

- space colours;

- entrances to the buildings;

- associated infrastructure (such as parking spaces, pedestrian crossings).

Finally, on the basis of the analysis, conclusions were drawn.

\section{RESULTS AND DISCUSSION}

\section{Legal aspects determining accessibility}

Counteracting discrimination in the access to public life constitutes a wellgrounded basis for providing requirements of planning accessibility. Legal provisions related to this issue can be found in the Constitution of the Republic of Poland and the Charter of Persons with Disabilities. The Charter clearly states that people with disabilities "have the right to lead an independent and active life and may not be discriminated against". On the other hand, the Constitution's provision that all citizens have equal rights is concise and clear, does not eliminate anyone and is not a basis to raise discrimination against anyone (Wysocki 2009). However, following Article $5 \S 1$ point 4 of the Construction Law, each "building object together with related construction devices should be, taking into account the expected period of use, designed and built in a manner specified in the provisions, including technical and construction, and following the principles of technical knowledge, ensuring the necessary conditions for the use of public buildings and multi-family housing by disabled persons, referred to in Article 1 of the Convention on the Rights of Persons with Disabilities ${ }^{3}$, including older people [own translation]". However, it is difficult to pinpoint a direct ref-

\footnotetext{
${ }^{3}$ According to the Convention, these are "people that have long-term physical, mental, intellectual or sensory impairment".
} 
erence to UOSs design; this issue will be further discussed in later considerations. Nevertheless, the above-mentioned general rule is described more precisely in the implementing provisions, which are indicated mostly in the Regulation of the Minister of Infrastructure of 12 April 2002 on the technical requirements to be met by buildings and their location. With the intention of determining which provisions that regulate accessibility refer to or could be applied in UOSs design, we thoroughly investigated this legal act and prepared the following overview in the table. In other statutes, one can also find provisions that include specific design guidelines. Among others, these include:

- Regulation of the Minister of Transport and Maritime Economy of 2 March 1999 on technical requirements to be met by public roads and their location (regulations such as stairs' and ramps' parameters, the cross slope of pedestrian routes or parameters of manhole covers and street inlets);

- Regulation of the Minister of Infrastructure of 17 June 2011 on the technical conditions to be met by metro building structures and their location (regulation such as the parameters of stairs and passenger lift cabins or guidelines for tactile paving for the blind).

Some of the provisions taken into consideration concern identical objects such as stairs or ramps; still, some can also slightly differ from each other, which hinders verification of the correction of their creation. With this in mind, we propose that the introduction of the standardisation of such regulations would contribute to their easier implementation.

\section{Urban open spaces}

Most of the provisions regarding accessibility aspects relate to public buildings, yet many of them could also be used in UOSs' design. The said legal acts do not provide a comprehensive definition of UOSs, hence it is difficult to refer them to specific cases. As accurately pointed out by Niedźwiecka-Filipiak and Zachariasz $^{4}$, the Construction Law does not refer to basic UOSs such as gardens, public parks, squares, or botanical and zoological gardens. This stems from the fact that recreational use is non-existent in the term sports and recreational facilities, which is precisely set out in the Polish Classification of Construction Facilities (in Polish Polska Klasyfikacja Obiektów Budowlanych). In this case, the very expression sports facilities indicates a lack of clear reference to basic UOSs in The Construction Law. It is necessary to underline at this point that accessibility planning requires not only precise design guidelines but it is also crucial to define where such rules should be applied. The goodwill of designers does not constitute a solution to the problem;

\footnotetext{
${ }^{4}$ In correspondence of 30 October 2018 addressed to the Ministry of Investment and Economic Development.
} 
TABLE. Legal provisions that determine accessibility (author's own elaboration on the basis of the Regulation of the Minister of Infrastructure of 12 April 2002 on the technical requirements to be met by buildings and their location). Table shows which paragraph of the regulation refers to a specific category of space elements in a given scope

\begin{tabular}{|c|c|c|c|c|c|c|c|}
\hline \multirow[b]{2}{*}{ Reference } & \multirow[b]{2}{*}{ Scope } & \multicolumn{6}{|c|}{ Category } \\
\hline & & 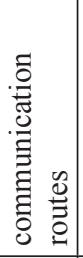 & 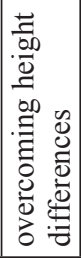 & 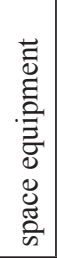 & 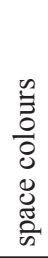 & 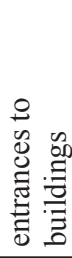 & 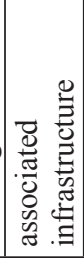 \\
\hline$\S 71.1,298.4-6$ & parameters of handrails located at the ramps & $\mathrm{X}$ & $\mathrm{X}$ & & & & \\
\hline$\S 62.2$ & providing alternative doors for revolving doors & & & & & $\mathrm{X}$ & \\
\hline$\S 62.1$ & door width & & & & & $\mathrm{X}$ & \\
\hline$\S 62.3$ & threshold height at the entrance door & & & & & $\mathrm{X}$ & \\
\hline$\S 75.3$ & prohibition of use thresholds & & & & & $\mathrm{X}$ & \\
\hline$\S 44.2,4$ & width of sidewalks depending on their location & $\mathrm{X}$ & & & & & \\
\hline$\S 44.3,6$ & determining the minimum width of sidewalks & $\mathrm{X}$ & & & & & \\
\hline$\S 54.4$ & minimum height of communication routes & $\mathrm{X}$ & & & & & \\
\hline$\S 294.2$ & $\begin{array}{l}\text { size of openings in manhole covers and street } \\
\text { inlets }\end{array}$ & $\mathrm{X}$ & & & & & \\
\hline$\S 127.8,11$ & minimum width and slope of the curb ramp & $\mathrm{X}$ & $\mathrm{X}$ & & & & \\
\hline$\S 21.1$ & dimensions of parking spaces & & & & & & $\mathrm{X}$ \\
\hline$\S 193.2 \mathrm{a}$ & dimensions of the elevator cabin & & $\mathrm{X}$ & $\mathrm{X}$ & & & \\
\hline$\S 195$ & location of the elevator entrance & & $\mathrm{X}$ & $\mathrm{X}$ & & & \\
\hline$\S 193.2 \mathrm{a}$ & $\begin{array}{l}\text { parameters of the elevator handrail and control } \\
\text { panel }\end{array}$ & & & $\mathrm{X}$ & & & \\
\hline$\S 68.1$ & stair steps parameters & $\mathrm{X}$ & $\mathrm{X}$ & & & & \\
\hline$\S 69.4$ & formula for the width of the steps & $\mathrm{X}$ & $\mathrm{X}$ & & & & \\
\hline$\S 69.5$ & shaping of the step profile & & $\mathrm{X}$ & & & & \\
\hline$\S 69.1,3$ & number of steps in a single flight of stairs & $\mathrm{X}$ & $\mathrm{X}$ & & & & \\
\hline$\S 296.1,3$ & use of handrails in the stairs & & $\mathrm{X}$ & & & & \\
\hline$\S 298.2$ & way of railings design & & $\mathrm{X}$ & & & & \\
\hline$\S 298.5$ & $\begin{array}{l}\text { extension of the handrail beyond the flight } \\
\text { of stairs }\end{array}$ & & $\mathrm{X}$ & & & & \\
\hline$\S 298.5,6$ & shape and location of the handrail & & $\mathrm{X}$ & & & & \\
\hline$\S 71.4$ & visual marking of the steps & & $\mathrm{X}$ & & $\mathrm{X}$ & & \\
\hline$\S 306.2$ & landings marking & & $\mathrm{X}$ & & $\mathrm{X}$ & & \\
\hline$\S 84.3$ & arrangement of toilets in an office building & & & & & & \\
\hline
\end{tabular}


TABLE cont.

\begin{tabular}{|c|c|c|c|c|c|c|c|}
\hline \multirow[b]{2}{*}{ Reference } & \multirow[b]{2}{*}{ Scope } & \multicolumn{6}{|c|}{ Category } \\
\hline & & 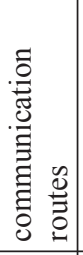 & 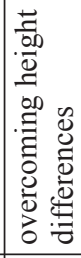 & 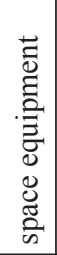 & 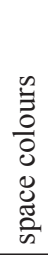 & 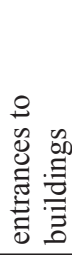 & 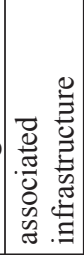 \\
\hline$\S 86.1$ & dimensions of the manoeuvring areas in toilets & $\mathrm{X}$ & & & & & \\
\hline$\S 86.2$ & $\begin{array}{l}\text { rules of designing vestibules in front of the } \\
\text { toilet }\end{array}$ & & & & & & \\
\hline$\S 53.2$ & greenery maintenance & $\mathrm{X}$ & & $\mathrm{X}$ & & & \\
\hline$\S 61.1$ & $\begin{array}{l}\text { considering entrances to buildings for the } \\
\text { disabled }\end{array}$ & & & & & $\mathrm{X}$ & \\
\hline$\S 295$ & marking transparent panels of door & & & $\mathrm{X}$ & & $\mathrm{X}$ & \\
\hline$\S 9,62,240$ & entrance door parameters & & & & & $\mathrm{X}$ & \\
\hline$\S 23.2$ & guidelines for marking transparent door panels & & & $\mathrm{X}$ & & $\mathrm{X}$ & \\
\hline$\S 70$ & permissible maximum incline of the ramp & & $\mathrm{X}$ & & & & \\
\hline$\S 71,298,306$ & ramp parameters & $\mathrm{X}$ & $\mathrm{X}$ & & & & \\
\hline $\begin{array}{l}\S 68,69,296, \\
298\end{array}$ & stair parameters & $\mathrm{X}$ & $\mathrm{X}$ & & & & \\
\hline$\S 54.2$ & equipping buildings with passenger lifts & & $\mathrm{X}$ & $\mathrm{X}$ & & & \\
\hline$\S 193,194,195$ & ensuring the accessibility of a passenger lift & & $\mathrm{X}$ & $\mathrm{X}$ & & & \\
\hline$\S 86.1$ & adaptation of toilets for the disabled & & & & & & \\
\hline$\S 55.2$ & $\begin{array}{l}\text { access to floors with utility rooms for the } \\
\text { disabled }\end{array}$ & & $X$ & & & & \\
\hline
\end{tabular}

therefore, changes in Polish legislation are needed to clarify the issues related to UOSs. The existing regulations can also lead to absurdities if not precise enough, and if common sense is vacant from the design process. A good example here is the ramp of considerable length in Siedlce (Fig. 1), which seems to be purposeless. In this case, $\S 70$ of Regulation of the Minister of Infrastructure of 12 April 2002 on the technical requirements to be met by buildings and their location should be more precise and needs additional clarification. This proves that it is deemed necessary to introduce a maximum length of entire ramps or the amount of landings. We believe that such action will contribute to the exclusion of similar occurrences. For instance, after exceeding the maximum length, there could be an obligation to design a stair platform.

Urban open spaces are places where people with special needs often have the only possibility to commune with nature. On these grounds, it is of the utmost importance to apply universal design principles whenever possible in order to provide said persons the opportunity to move safely and comfortably. 


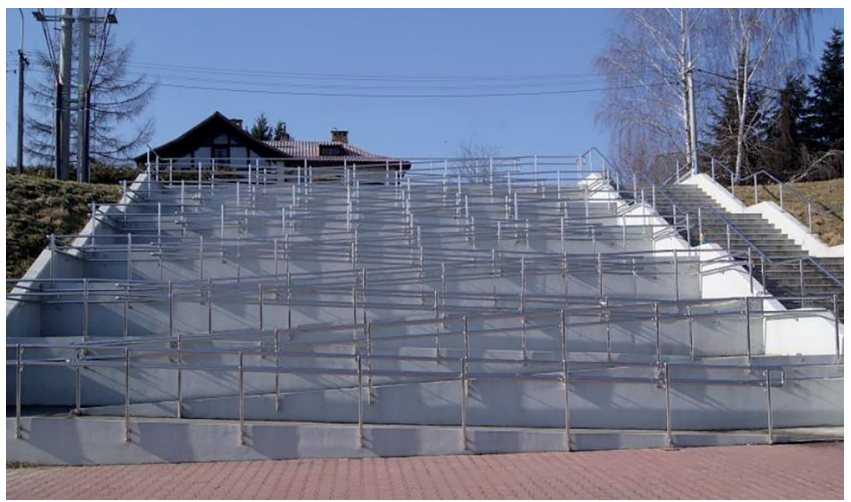

FIGURE 1. Ramp of considerable length in Siedlce, Poland (Pastor 2014)

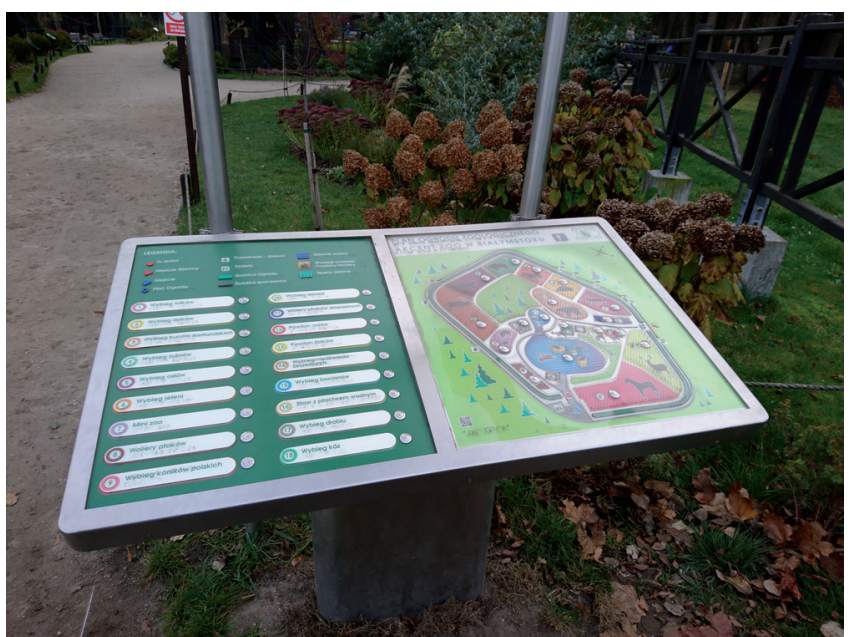

FIGURE 2. Typhlographic plan of the zoological garden, with audio descriptions (photo by K.L. Rawski)

Currently, typical green areas are usually fitted to the needs of active, physically efficient, and well-sighted people. However, it should be emphasised that adjusting a place to the mobility of various individuals does not indicate that it will be frequented by them. When designing UOSs, in addition to secluded places for passive recreation, places for active leisure should be taken into account. Therefore, it is important to make a diversified functional and spatial programme. With seniors in mind, it is good practice, e.g. to place exercise equipment in small areas near traffic routes (Jankowski et al. 2013). Parks should be designed in such a way that all users, both young and older, encountering more barriers on their way, are taken into consideration. We are confident that involving such people can improve their surroundings through social participation. To illustrate, adaptation of the Białystok zoological garden through participatory budgeting (in 
Polish budżet obywatelski) ${ }^{5}$ resulted in a path for the blind, tactile plans and information boards with audio descriptions (Fig. 2).

\section{Development of Polish law}

In 2018, a governmental programme "Accessibility Plus", with a budget of approximately PLN 23 billion for the years 2018-2025, was introduced (MIiR 2018). Its main goal is to improve accessibility in eight areas, namely architecture, transport, education, health care, digitisation, services, competitiveness, and coordination. When it comes to services, at "Activity 26" (sport, tourism, and recreation without barriers), it is planned "to improve accessibility of recreational space: e.g. beaches and waterside areas, green areas - parks and gardens, outdoor gyms and integrated playgrounds, forest parking lots, tourist attractions located within them and in their surroundings, etc." (MIiR 2018, p. 51).

Among the main postulates of the above programme was also the introduction of a new law, the so-called Accessibility Act, which entered into force on 20th September as the Act of 19 July 2019. Ensuring accessibility for people with special needs, it defines terms such as: barrier, accessibility, person with special needs, universal design. The Act also specifies recommendations for universal design in the field of accessibility: architectural, digital, as well as information and communication. Architectural accessibility, the main focus here, mainly

\footnotetext{
${ }^{5}$ Participatory budgeting is a process in which city inhabitants decide to allocate public funds to areas of their choosing.
}

determines the adaptation or design of buildings, as discussed in Article 6 point 1 of this Act. It presents the following minimum requirements to be met when providing accessibility for incapacitated individuals:

a) "ensuring barrier-free horizontal and vertical communication spaces of buildings;

b) installation of equipment or the use of technical measures and architectural solutions in the building that allow access to all rooms, except for technical rooms;

c) providing information about the layout of rooms in the building, at least in a visual and tactile or voiced way;

d) providing access to the building for a person using an assistance $\operatorname{dog}$, referred to in Article 2 point 11 of the Act of 27 August 1997 on professional and social rehabilitation, and employment of disabled people (Journal of Laws of 2019, item 1172 and 1495);

e) ensuring that persons with special needs will be able to evacuate or otherwise be rescued [own translation]". While the governmental programme "Accessibility Plus" describes plans to improve UOSs accessibility as one of the core activities, the Accessibility Act only introduces the amendment to the Act of 16 April 2004 on Nature Protection. The amendment (contained in Art. 50 of the new Act) concerns new obligations for public administrative authorities to ensure accessibility of various forms of nature protection within the meaning of Article 6 of the Act on Nature Protection. This encompasses national parks, nature reserves, landscape parks, protected landscape areas, and other forms of na- 
ture. As a result, ultimately, people with special needs should have better opportunities to visit such places or, alternatively, to explore their resources as part of the national and natural wealth (Portal Funduszy Unijnych (n.d.). The new law, however, only sets out the minimum and general requirements for accessibility that given institutions must implement. Information about the implementation of the Accessibility Act is described in a separate document - a dedicated guide, in the form of recommendations (Kowalski et al. 2019). What is more, accessibility will be verified by appointed coordinators after the period of adaptation to changes, i.e. from 30 September 2020. However, the first report on the state of the country accessibility does not have to be published until 2021.

Another postulate of the governmental programme "Accessibility Plus" aimed at improving accessibility is to introduce universal design into university curricula, including the landscape architecture. Considering the profession of a landscape architect, since the introduction of the 2018 Regulation of the Minister of Science and Higher Education, the title of landscape architect has been disregarded as a possible title to be granted upon graduation in landscape architecture. Additionally, there is a lack of a regulated issue of entitlement to practice this profession (Drabiński 2007). Such an approach is not conducive to the implementation of the assumptions from "Activity 26" of the programme (sport, tourism, and recreation without barriers), i.e. in the field of "services". Thus, in this case, some actions of authorities seem to be inconsistent, as we strongly believe it is landscape architects who should be responsible for improving the quality of UOSs. This has also been put forward by individual organisations (e.g. Stowarzyszenie Polskich Architektów Krajobrazu - Association of Polish Landscape Architects) but to no avail.

\section{International background}

Although the Polish law contains a number of legal provisions regarding accessibility, it is difficult to clearly determine whether such provisions meet European or international standards if these are not compared in a wider perspective. There are many highly developed countries, such as the USA, GB, Canada, Australia, and Scandinavia, which as early as 1990 s began implementing ideas of universal design. Analysing the assumptions of universal design in these countries one may come across, among others, such documents as the "Americans with Disabilities Act" or "Design and Access Statements". We propose that collating various regulations from individual acts will certainly allow to determine the state of Polish regulations, and at the same time will offer a possibility to indicate any deficiencies. There is undoubtedly a room for further research: precise analysis of the existing guidelines will allow for building a unified accessibility design model for UOSs. It is also vital to accurately specify spaces specific guidelines should refer to, so as to minimise the risk legal loopholes.

\section{CONCULSIONS}

Easy access to public buildings and green areas is the first step to preventing social exclusion. It is thus important 
to improve UOSs' quality and accessibility so that people with special needs can freely and, above all, safely commune with nature outside their habitation. Analysing Polish legal acts and the changes they are aiming at, the following conclusions can be drawn. Firstly, the Polish Government in cooperation with many social organisations recognises the need to improve UOSs' accessibility; however, implementing some of the assumptions is time-consuming. Secondly, there exists a number of legal provisions that determine accessibility; however, one must legally define UOSs to oblige interested parties to make use of the already-existing recommendations. Furthermore, new specialists skilled at conducting accessibility audits to meet the requirements of the new law are urgently needed. Next, the profession of a landscape architect, so far marginalised, could play a greater role in adapting the space for people with special needs. The introduction of an appropriate license for UOSs' design would be a significant step towards improving their quality and accessibility. Finally, further research into Polish regulations juxtaposed with other developed countries as well as international regulations is also recommended. Conducting an appropriate comparative analysis will allow determining whether the Polish approach to universal design meets international standards.

\section{Acknowledgements}

The article was prepared within the framework of the research work W/ /WBiIŚ/22/2019 carried out at Bialystok University of Technology and financed from the subsidy provided by the Minister of Science and Higher Education.

\section{REFERENCES}

Convention on the Rights of Persons with Disabilities [without reference to a Main Committee (A/61/611)] (A/RES/61/106).

DRABIŃSKI A. 2007: Legal aspects of the profession of a landscape architect. Czasopismo Techniczne. Architektura R. 104, 5-A: 197-199.

DYMICKA M. 2013: Przestrzeń publiczna a przemiany miasta. Wydawnictwo $\mathrm{Na}-$ ukowe Scholar, Warszawa.

JANKOWSKI K., SOSNOWSKI J., WIŚNIEWSKA-KADŻAJN B., TRUBA M., HERDA D. 2013: Organization of Rest and Recreation in Urban Green Areas. Zeszyty Naukowe Uniwersytetu Przyrodniczo-Humanistycznego w Siedlcach. Administracja i Zarządzanie 25: 13-21.

KACZMAREK S., KACZMAREK J. 2011: Teoretyczne podstawy studiów nad przestrzenią gościnności. In: M. Durydiwka, K. Duda-Gromada (Eds.), Przestrzeń turystyczna: czynniki, różnorodność, zmiany. Wydział Geografii i Studiów Regionalnych UW, Warszawa: 65-74.

Konstytucja Rzeczypospolitej Polskiej z dnia 2 kwietnia 1997 r. Dz.U. 1997 nr 78, poz. 483 [Constitution of the Republic of Poland of 2 April 1999. Journal of Laws 1997 No 78, item 483].

KOWALSKI K. 2013: Planowanie dostępności - polskie uwarunkowania prawne i praktyka. Niepełnosprawność - zagadnienia, problemy, rozwiązania 1 (6): 71-99.

KOWALSKI P., MIKOŁAJCZYK A., ZIMNY B. 2019: Jak wdrażać Ustawę o zapewnianiu dostępności? The Ministry of Investment and Economic Development, Łódź.

LORENS P., MARTYNIUK-PECZEK J. (Eds.) 2010: Problemy kształtowania 
przestrzeni publicznych. Urbanista, Gdańsk.

MADDEN K., WILEY-SCHWARTZ A. 2005: How to turn a place around: a handbook for creating successful public spaces. Project for Public Spaces, New York, NY.

Ministerstwo Inwestycji i Rozwoju - MIiR [Ministry of Investment and Economic Development] 2018: Standardy dostępności dla polityki spójności 2014-2020. Wytyczne w zakresie realizacji zasady równości szans i niedyskryminacji, w tym dostępności dla osób z niepełnosprawnościami oraz zasady równości szans kobiet i mężczyzn w ramach funduszy unijnych na lata 2014-2020. Retrieved from: https://www.funduszeeuropejskie. gov.pl/strony/o-funduszach/dokumenty/wytyczne-w-zakresie-realizacji-zasady-rownosci-szans-i-niedyskryminacjioraz-zasady-rownosci-szans [accessed: 15.03.2020].

Ministerstwo Inwestycji i Rozwoju - MIiR [Ministry of Investment and Economic Development] 2018. Governmental programme. Accessibility Plus 2018-2025. The Ministry of Investment and Economic Development, Warszawa. Retrieved from: https://www.funduszeeuropejskie. gov.pl/media/72628/Dostepnosc_angielski.pdf [accessed: 15.03.2020].

PASTOR Ł. (2014). Winda czy rampa? Jak zwykle decydują pieniądze. TransportPubliczny.pl. Retrieved from: https:// www.transport-publiczny.pl/mobile/winda-czy-rampa-jak-zwykle-decyduja-pieniadze-1698.html [accessed: 15.03.202].

Portal Funduszy Unijnych (n.d.): Uzasadnienie do ustawy z dnia 19 lipca 2019 r. [Explanation to the Act of 19 July 2019 on ensuring accessibility for people with special needs]. Retrieved from: https:// www.funduszeeuropejskie.gov.pl/media/82729/uzasadnienie do ustawy 19lipca2019.pdf [accessed: 16.03.2020].

Rozporządzenie Ministra Infrastruktury z dnia 12 kwietnia 2002 r. w sprawie warunków technicznych, jakim powinny odpowiadać budynki i ich usytuowanie. Dz.U. $2011 \mathrm{nr} 75$, poz. 690 [Regulation of the Minister of Infrastructure of 12 April 2002 on the technical requirements to be met by buildings and their location. Journal of Laws 2011 No 75, item 690].

Rozporządzenie Ministra Infrastruktury $\mathrm{z}$ dnia 17 czerwca $2011 \mathrm{r}$. w sprawie warunków technicznych, jakim powinny odpowiadać obiekty budowlane metra i ich usytuowanie. Dz.U. $2011 \mathrm{nr}$ 144, poz. 859 [Regulation of the Minister of Infrastructure of 17 June 2011 on the technical conditions to be met by metro building structures and their location. Journal of Laws 2011 No 144, item 859].

Rozporządzenie Ministra Nauki i Szkolnictwa Wyższego z dnia 27 września 2018 r. w sprawie studiów. Dz.U. 2018, poz. 1861 [Regulation of the Minister of Science and Higher Education of 27 September 2018 on studies. Journal of Laws 2018, item 1861].

Rozporządzenie Ministra Transportu i Budownictwa z dnia 2 marca 1999 r. w sprawie warunków technicznych, jakim powinny odpowiadać drogi publiczne i ich usytuowanie. Dz.U. 1999 nr 43, poz. 430 [Regulation of the Minister of Transport and Maritime Economy of 2 March 1999 on the technical requirements to be met by public roads and their location. Journal of Laws 1999 No 43, item 430].

RYMSZA B., MIŚKOWIEC M. 2017: Standardy dostępności dla Miasta Stołecznego Warszawy. 2nd edn. Warszawa.

SARP Warszawa 2017: Spacery OW SARP - obiekt architektury krajobrazu i jego twórca. Retrieved from: https://sarp. warszawa.pl/spacery-ow-sarp-obiekt-architektury-krajobrazu-i-jego-tworca-bulwary-wislane-autorstwa-rs-architekturakrajobrazu [accessed: 29.02.2020].

TOTA P. 2019: Wrocławskie standardy dostępności przestrzeni miejskich. Wrocław.

Uchwała Sejmu Rzeczypospolitej Polskiej z dnia 1 sierpnia 1997 r. - Karta Praw Osób Niepełnosprawnych. Dz.U. 1997 
nr 50, poz. 475 [Charter of the Rights of People with Disabilities of 1 August 1997. Journal of Laws 1997 No 50, item 475].

Ustawa z dnia 16 kwietnia 2004 r. o ochronie przyrody. Dz.U. 2018, poz. 1614, z póź. zm. [Act of 16 April 2004 on nature protection. Journal of Laws 2018, item 1614, as amended].

Ustawa z dnia 19 lipca 2019 r. o zapewnianiu dostępności osobom ze szczególnymi potrzebami. Dz.U. 2019, poz. 1696 [Act of 19 July 2019 on ensuring accessibility for people with special needs. Journal of Laws 2019, item 1696].

Ustawa z dnia 21 marca 1985 r. o drogach publicznych. Dz.U. 1985 nr 14, poz. 60 [Act of March 21 March 1985 on public roads. Journal of Laws 1985 No 14, item $60]$.

Ustawa z dnia 27 marca 2003 r. o planowaniu i zagospodarowaniu przestrzennym. Dz.U. 2003 nr 80, poz. 717 [Act of 27 March 2003 on spatial planning and development. Journal of Laws 2003 No 80, item 717].

Ustawa z dnia 7 lipca 1994 r. - Prawo budowlane. Dz.U. 2010 nr 243, poz. 1623, z póź. zm. [Act of 7 July 1994 - the Construction Law. Journal of Laws 2010 No 243, item 1623, as amended].

WEJCHERT K. 1993: Przestrzeń wokół nas. Fibak Noma Press, Katowice.

WYSOCKI M. 2009: Dostępna przestrzeń publiczna. Fundacja Instytut Rozwoju Regionalnego, Kraków. Retrieved from: http://www.firr.org.pl/uploads/PUB/ Dostepna przestrzen publiczna.pdf [accessed: 19.03.2020].

WYSOCKI M. 2013: Standardy dostępności dla miasta Gdyni. Centrum Projektowania Uniwersalnego, Gdynia.

Streszczenie: Dostępność krajobrazu w świetle polskiego prawa. Czy każdy może korzystac z obiektów architektury krajobrazu? W artyku- le przedstawiono problematyke projektowania obiektów architektury krajobrazu (OAK) w kontekście ich dostępności dla różnych użytkowników. Przeanalizowano aspekty, jakie powinno uwzględniać się na etapie projektowania tak, aby przestrzeń stała się przede wszystkim dostępna i bezpieczna dla osób ze specjalnymi potrzebami Omówiono także zagadnienia związane z zapisami prawnymi, które określają wytyczne projektowe poszczególnych elementów przestrzeni, oraz przeanalizowano je w odniesieniu do projektowania OAK. Poruszono także tematykę związaną ze wspieraniem osób niepełnosprawnych przez rząd w postaci programu „Dostępność Plus” czy też opracowania nowej ustawy o zapewnianiu dostępności osobom ze szczególnymi potrzebami. Celem niniejszej publikacji jest również próba określenia ogólnego stanu dostępności OAK na terenie Polski na podstawie istniejących zapisów prawa. Niezobowiązujące projektantów do planowania dostępności regulacje prawne nie mogą zapewnić dostępności OAK. Przepisy prawne powinny być określone jako przejrzyste wytyczne. Obecnie polski rząd próbuje poprawić aktualną sytuację, ale zdaniem autora potrzebne są dalsze zmiany.

Stowa kluczowe: projektowanie uniwersalne, dostępność, obiekty architektury krajobrazu, osoby niepełnosprawne, osoby ze specjalnymi potrzebami, bariery

MS received: 20.04 .2020

MS accepted: 30.07 .2020

\section{Author's address:}

Kamil Leszek Rawski (https://orcid.org/0000-0002-3845-4556)

Wydział Architektury

Politechnika Białostocka

ul. Sosnowskiego 11, 15-893 Białystok

Poland

e-mail: k.rawski@pb.edu.pl 